\title{
Simbolisasi Punokawan dalam Iklan
}

\author{
Meirina Lani Anggapuspa
}

Staff Pengajar Jurusan Pendidikan Seni Rupa, Fakultas Bahasa dan Seni,

Universitas Negeri Surabaya

Email : meyrina.lani@gmail.com

Abstract - Advertising in its function as a medium conveys the message, of course, have a variety of ways to convey the message properly to the audience, one of which is through symbolization Punokawan figure. Punokawan are officials in the puppet character that is not just qualified, but can also directing, comforting, encouraging, and motivating. Use of this Punokawan figures, aims to bring back the ethos and nature of mutual assistance (bebarengan mrantasi gawe) that characterize the people of Yogyakarta. In addition, these symbolization Punokawan also able to arouse the human willingness to back attitude with a calm and humble, without the prestige and show off everyday to fulfill its obligations, and seek not to impose its own sake, for the sake of harmony in the society Playing the disaster and post-disaster reconstruction.

Keyword:Punokawan, symbol, advertisement

\section{PENDAHULUAN}

Atas jasa Morris dan Ruskin, tokoh revolusi industri di Inggris pada abad ke19, kata desain kemudian dimaknai sebagai art and craft, yaitu paduan antara seni dan keterampilan. Pada masa revolusi industri dan masa-masa sesudahnya, kegiatan desain dikenal sebagai Industrial Art, Commercial Art, Applied Art, Machine Art, Decorative Art, dan sebagainya.
Perkembangan selanjutnya di Indonesia, kegiatan desain dibagi menjadi desain interior (ruang dalam), desain arsitektur (bangunan), desain tekstil, desain grafis, dan desain produk industri.

Desain, pada awalnya merupakan kata baru berupa peng-Indonesiaan dari kata design, istilah ini melengkapi kata "rancang/rancangan/merancang" yang dinilai kurang mengekspresikan keilmuan, keluasan dan kewibawaan profesi. Sejalan dengan itu, kalangan insinyur menggunakan istilah rancang bangun, sebagai pengganti istilah desain.Namun di kalangan keilmuan seni rupa istilah "desain" tetap secara konsisten dan formal dipergunakan (Sachari, 2005:3).

Desain komunikasi visual merupakan ilmu maupun profesi yang mengkaji dan mempelajari desain dengan berbagai pendekatan dan pertimbangan, baik yang menyangkut komunikasi, media, citra, tanda maupun nilai.Dari aspek keilmuan, desain komunikasi visual juga mengkaji hal-hal yang berkaitan dengan komunikasi dan pesan, teknologi percetakan, penggunaan teknologi 
multimedia, dan teknik persuasi pada masyarakat.Cenadi (1999:4) menjelaskan pengertian Desain komunikasi visual sebagai desain yang mengkomunikasikan informasi dan pesan yang ditampilkan secara visual.Desainer komunikasi visual berusaha untuk mempengaruhi sekelompok pengamat. Mereka berusaha agar kebanyakan orang dalam target grup (sasaran) tersebut memberikan respon positif kepada pesan visual tersebut. Oleh karena itu desain komunikasi visual harus komunikatif, dapat dikenal, dibaca dan dimengerti oleh target group tersebut.

Dalam perkembangannya selama beberapa abad, desain komunikasi visual menurut Cenadi (1999:4) mempunyai tiga fungsi dasar, yaitu sebagai sarana identifikasi, sebagai sarana informasi dan instruksi, dan sebagai sarana promosi.Fungsi dasar yang utama dari desain komunikasi visual adalah sebagai sarana identifikasi.Identitas seseorang dapat mengatakan tentang siapa orang itu, atau dari mana asalnya. Demikian juga dengan suatu benda, produk ataupun lembaga, jika mempunyai identitas akan dapat mencerminkan kualitas produk atau jasa itu dan mudah dikenali, baik oleh baik oleh produsennya maupun konsumennya.

Selain sarana identifikasi, tujuan dari desain komunikasi visual adalah menyampaikan pesan, mendapatkan perhatian (atensi) dari mata (secara visual) dan membuat pesan tersebut dapat diingat; contohnya iklan surat kabar. Penggunaan gambar dan kata-kata yang diperlukan sangat sedikit, mempunyai satu makna dan mengesankan.Umumnya, untuk mencapai tujuan ini, maka gambar dan kata-kata yang digunakan bersifat persuasif dan menarik, karena tujuan akhirnya adalah menjual suatu produk atau jasa.Isi pesan dan unsur-unsur pada iklan memiliki kedalaman karakter dan visi-misi produk yang diiklankan, selain itu memiliki kesesuaian terhadap sosio-historis dan fenomena yang sedang terjadi.

Tahun 2007, setahun pasca gempa bumi hebat yang meluluhlantakkan Yogyakarta (terutama wilayah selatan), surat kabar Kedaulatan Rakyat meluncurkan iklan berseri sebagai promosi pribadi yang merespon peringatan satu tahun gempa bumi di Yogyakarta dengan tema besar "Migunani Tumraping Liyan".

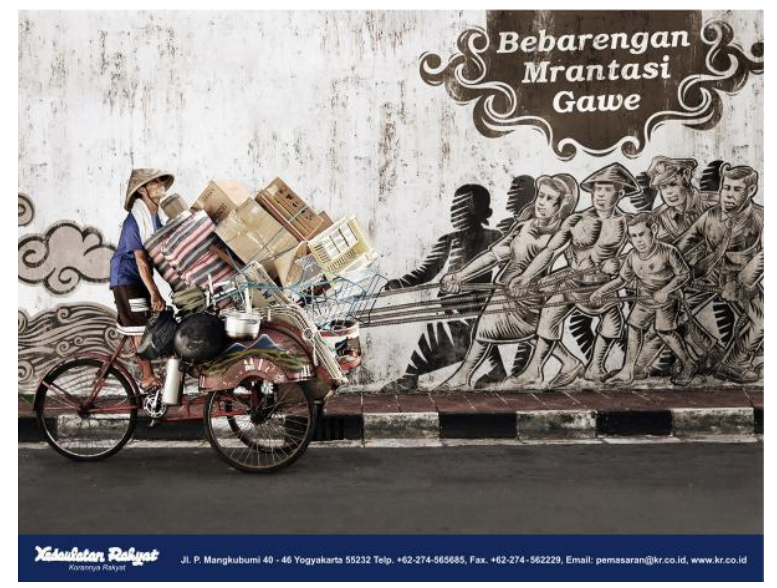

Gambar 1. Seri 1 - Iklan Migunani Tumraping Liyan

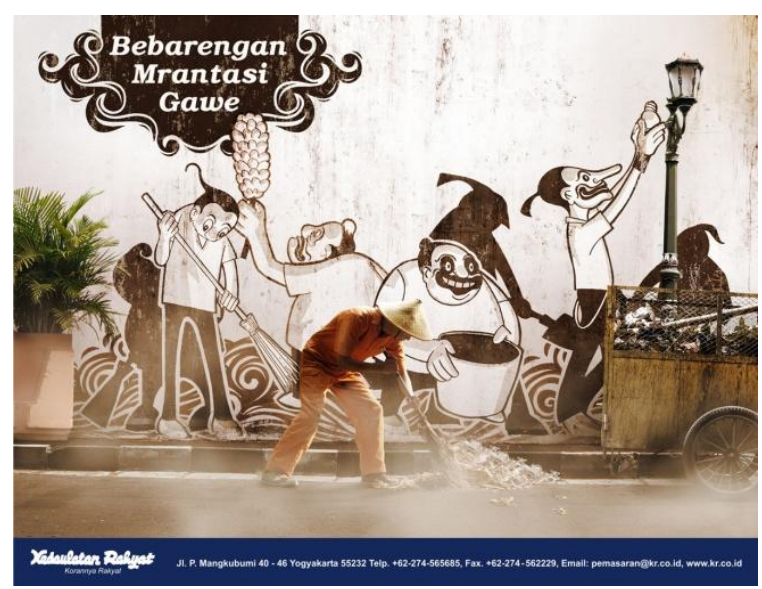

Gambar 2. Seri 2 - Iklan Migunani Tumraping Liyan 


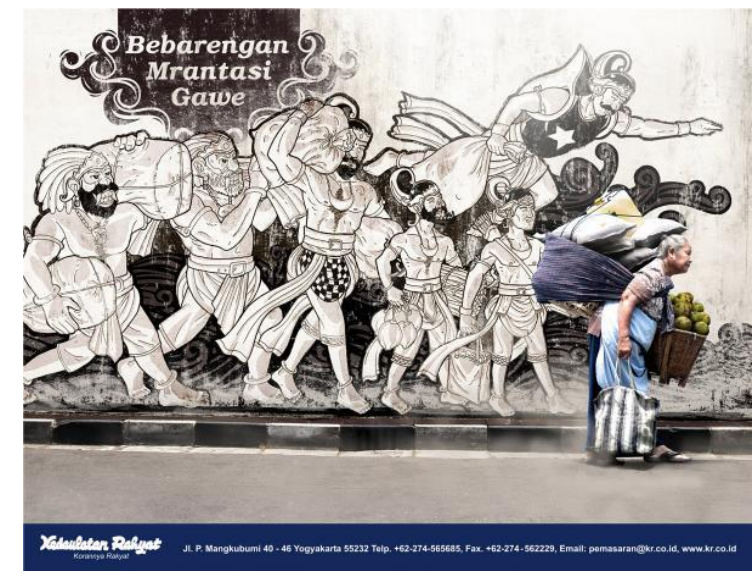

Gambar 3. Seri 3 - Iklan Migunani Tumraping Liyan

\section{Punokawan}

Punokawan merupakan bagian dari dunia wayang yang hanya ada di Indonesia, karena di dalam cerita asli pewayangan di India tidak ada tokoh Punokawan. Sedangkan kesenian wayang sendiri sudah ada sejak sebelum kebudayaan Hindu masuk ke Indonesia dan melekat begitu kuat dalam kebudayaan Jawa (Bedjo, 2004: 38).

Punokawan yang dalam pewayangan juga disebut punokawan, adalah pamong.Kata panakawan berarti teman yang multifungsi, yang mumpuni, yang bukan saja mengawani tetapi juga mengarahkan, menghibur, memberi semangat, dan memotivasi.Kata panakawan artinya adalah teman yang tahu, yang faham.Kata pana artinya tahu atau faham, sedangkan kawan berarti teman.

Berdasarkan sejarahnya, Punokawan atau juga disebut Panakawan lahir di bumi Indonesia. Tokoh Punokawan yang terdiri atas Semar, Nala Gareng, Petruk dan Bagong dibuat sedemikian rupa mendekati kondisi masyarakat Jawa yang beraneka ragam, karakternya mengindikasikan bermacam-macam peran, seperti penasehat para ksatria, penghibur, kritisi sosial, badut bahkan sumber kebenaran dan kebajikan. Dalam wayang Bali karakter Punokawan terdiri atas Tualen (Malen) dan Merdah (abdi dari Pandawa) serta Delem dan Sangut (abdi dari Kurawa).

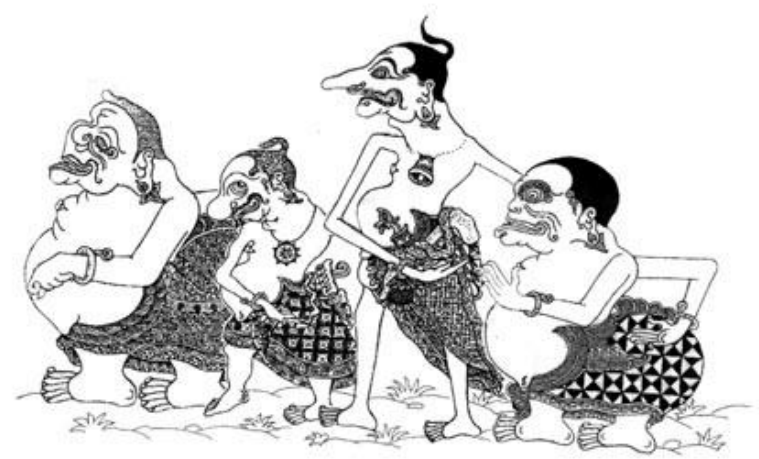

Gambar 4. Tokoh Punokawan Wayang kulit Purwa, dari kiri ke kanan, Semar, Gareng, Petruk, dan Bagong

Masing-masing tokoh Punokawan dalam wayang kulit purwa memiliki karakter yang khas dan penuh makna:

a) Semar

Pengasuh para Pandawa, ia juga bernama Hyang Ismaya. Meskipun berwujud manusia jelek, namun memiliki kesaktian yang sangat tinggi bahkan melebihi para dewa.

b) Gareng

Putra Semar yang berarti pujaan atau didapatkan dengan memuja. Nalagareng adalah seorang yang tidak pandai bicara, apa yang dikatakannya kadang-kadang serba salah. Tetapi sangat lucu dan menggelikan.

c) Bagong

Bagong berarti bayangan Semar. Ketika diturunkan ke dunia Dewa bersabda pada Semar bahwa bayangannyalah yang akan menjadi temannya. Seketika itu juga bayangannya berubah wujud menjadi Bagong, yang memiliki sifat 
lancang dan berlagak bodoh, tapi sangat lucu.

d) Petruk

Putra Semar yang bermuka manis dengan senyuman yang menarik hati, pandai berbicara dan juga sangat lucu.

Petruk suka menyindir ketidakbenaran dengan lawakan-lawakannya.

\section{Iklan}

Iklan merupakan salah satu faktor kebudayaan paling penting yang mencetak dan merefleksikan kehidupan kita saat ini. Iklan ada dimana-mana, sebagai bagian tak terelakkan dari kehidupan setiap orang. Dengan menjalari semua media, dan tidak dibatasi pada siapa pun, periklanan membentuk sebuah suprastruktur luas dengan eksistensi yang tampak otonom dan disertai pengaruh yang sangat besar (Williamson, 2007:1).

Periklanan merupakan sarana penting yang digunakan perusahaan untuk menyampaikan informasi tentang produk atau jasa kepada konsumen sasarannya. Adapun menurut Kamus Istilah Periklanan Indonesia, periklanan atau dalam bahasa Inggris disebut sebagai "advertising" memiliki pengertian (Nuradi, 1996:4):

Pesan yang dibayarkan serta disampaikan melalui sarana media (pers, radio, televisi, bioskop, dan seterusnya) yang mempunyai tujuan membentuk konsumen untuk melakukan tindakan pembelian atau mengubah perilakunya.

Secara sederhana iklan dapat diberi pengertian sebagai sebuah pesan yang menawarkan sebuah barang atau jasa yang ditujukan kepada masyarakat melalui sebuah media. Sebagai tool/alat komunikasi pemasaran, iklan memiliki beberapa fungsi dan tujuan. Adapun fungsi dan tujuannya sebagai berikut:

a. Menginformasikan (informing) suatu bentuk produk atau jasa kepada khalayak.

b. Mempersuasi (persuading) khalayak untuk mengkonsumsi suatu produk atau jasa yang ditawarkan.

c. Mengingatkan (reminding) kepada khalayak akan eksistensi suatu produk atau jasa yang ada di pasar.

d. Menambah nilai (adding value) seperti: adanya inovasi, peningkatan kualitas produk dan mengubah persepsi konsumen.

e. Membantu upaya atau usaha perusahaan yang lain.

Iklan yang baik adalah iklan yang mampu menyampaikan pesan penjualan kepada khalayak secara kreatif. Namun pada hakekatnya sebuah karya iklan yang baik seyogyanya harus memenuhi prinsipprinsip sebagaimana terangkum dalam formulasi AIDA sebagai berikut :

1. Attention (Perhatian)

Sebuah iklan sebisa mungkin harus bisa memperoleh perhatian dari target audience berkaitan dengan aksi periklanan yang dilakukan.

2. Interest (Ketertarikan)

Sebuah iklan yang disusun hendaknya harus dapat menimbulkan rasa ketertarikan pada target audience yang dituju.

3. Desire (Keinginan) 
Sebuah iklan sebaiknya bisa membuat target audience menjadi menginginkan produk maupun jasa yang ditawarkan.

4. Action (Tindakan)

Iklan dikatakan berhasil apabila bisa membujuk target audience untuk melakukan pembelian atas barang atau jasa yang ditawarkan.

Meski begitu, membuat sebuah karya iklan bukanlah suatu perkara yang gampang. Diperlukan suatu disiplin tersendiri untuk membuat karya iklan bermanfaat untuk membangun merek maupun mendongkrak omzet penjualan produk. Namun sesungguhnya tidak terdapat resep yang baku, sebagaimana terpapar di atas, untuk melahirkan sebuah karya iklan sesuai dengan yang dikehendaki.

Iklan bukan semata-mata pesan bisnis yang menyangkut usaha mencari keuntungan secara sepihak. Iklan juga mempunyai peran yang sangat penting bagi berbagai kegiatan nonbisnis. Di negara-negara maju, iklan telah dirasakan manfaatnya dalam menggerakkan solidaritas masyarakat manakala menghadapi suatu masalah sosial. Dalam iklan tersebut disajikan pesan-pesan sosial yang dimaksud untuk membangkitkan kepedulian masyarakat terhadap sejumlah masalah yang harus dihadapi, yakni kondisi yang bisa mengancam keserasian dan kehidupan umum. Iklan seperti itu menurut Kasali (1992: 201) disebut iklan layanan masyarakat (ILM).

Misalnya, ILM gerakan anti narkoba, subsidi listrik, hemat listrik, pemilu yang jujur dan adil, kebakaran hutan, bencana alam, kerukunan agama, ras dan suku, pelestarian lingkungan hidup, konservasi hutan, imunisasi nasional, membudayakan pengunaan helm dan sabuk pengaman, tertib lalulintas, dan sebagainya. Biasanya tema-tema tersebut disesuaikan dengan masalah nasional yang sedang aktual di tengah masyarakat.

\section{Media Cetak}

Media mempunyai peran yang sangat penting dan strategis bagi kegiatan periklanan, karena lewat medialah suatu pesan dapat diwujudkan dan disampaikan sehingga dapat ditangkap panca inderakonsumennya. Bagian visual dari sebuah media cetak (print ad)haruslah menarik perhatian, menyampaikan sebuah ide atau citra dan mampu bekerja secara sinergis dengan headline dan body copy untuk menghasilkan pesan secara efektif. Banyak keputusan yang dapat diambil berkaitan dengan komponen visual dalam print ad. Tetapi yang jelas harus memuat item penting seperti nama produk, perusahaan penghasil produk itu, logo, alamat perusahaan dan kaitannya.

Sebagai bagian dari media komunikasi visual, media cetak merupakan media statis yang mengutamakan pesan-pesan visual. Media ini terdiri dari lembaran dengan sejumlah kata-kata, gambar, atau fotografi, dalam suatu tata warna serta halaman putih. Seperti halnya jenis media komunikasi yang lain (media audio atau media audio visual), fungsi utama media cetak adalah sebagai wahana penyampai pesan dan sekaligus sebagai media penghibur yang dapat memuaskan perasaan keindahan pemirsanya. Media cetak merupakan suatu dokumen yang merekam segala peristiwa dalam 
kehidupan masyarakat, yang ditangkap oleh jurnalis atau desainernya dan kemudian diubah dalam bentuk informasi yang berupa kata-kata, gambar, fotografi dan sebagainya. Dalam hubungannya dengan kegiatan periklanan yang disebut sebagai media cetak adalah surat kabar, majalah, maupun media-media lain yang diproduksi lewatproses cetak-mencetak (poster, selebaran, brosurdan lain-lain). Sehingga pengertian iklan media cetak adalah pesan-pesan komersial dari produsen kepada khalayak konsumennya yang disampaikan lewat media cetak (Kasali, 1992:99).

Dalam media cetak, kecenderungan pemakaian terlalu banyak unsur dekorasi grafis serta bermain "gila" dengan begitu banyak typhography hanya menjebak ke dalam keruwetan dan mematikan ide besamya. Ide besar dalam periklanan adalah yang mengandung sisi keseharian dalam kehidupan manusia dan berhubungan dengan target audience. Peristiwa sehari-hari adalah kunci untuk membuat periklanan menjadi segar, menarik, dan relevan.

\section{Simbol}

Adalah tanda yang menunjukkan hubungan alamiah antara penanda dan petanda (Sobur, 2004: 41).Simbol merupakan salah satu jenis tanda yang bersifat arbitrer dan konvensional. Dengan demikian, berdasarkan pengertian ini, simbol merupakan ekuivalen dari pengertian Saussure tentang tanda. Saussure menyatakan, bahasa merupakan entitas psikologis yang berisi dua atau berdwimuka, terdiri dari unsur penanda (citra-bunyi) dan petanda (konsep). Kedua elemen tanda tersebut sungguh-sungguh menyatu dan saling tergantung satu sama lain. Kombinasi dari suatu konsep (signifie=petanda) dan suatu citra bunyi (signifiant=penanda) inilah yang kemudian menghasikan tanda (Budiman, 1999: 115). Tanda-tanda kebahasaan pada umumnya adalah simbol. Rambu lalu lintas berbentuk lingkaran berwarna merah dengan sebuah garis putih melintang ditengahnya, adalah salah satu simbol yang menyatakan larangan masuk bagi semua kendaraan. Istilah simbol biasa dipergunakan secara luas dengan pengertian yang beraneka ragam, akan tetapi tentunya harus selalu dipahami secara hati-hati (Budiman, 1999: 109).

\section{PEMBAHASAN}

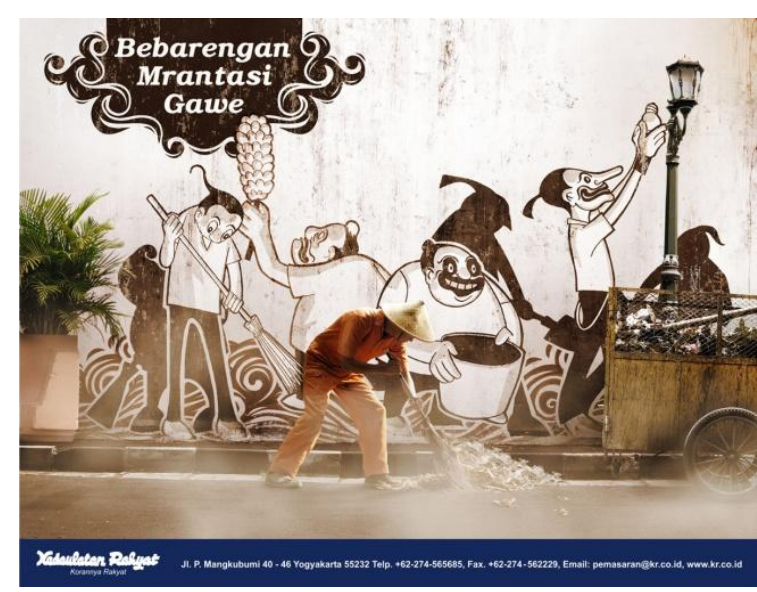

Iklan harian Kedaulatan Rakyat (KR) Bebarengan Mrantasi Gawe versi Nyapu ini dibuat dalam posisi landscape (horizontal), dan full colour. Disebelah kiri atas terdapat headline yang tertulis Bebarengan Mrantasi Gawe dengan warna putih dan background hitam. Di ujung kiri pada gambar terdapat sebuah pot bunga berwarna peach lengkap dengan tanamannya. Disebelahnya terdapat sosok laki-laki menggunakan kaos 
putih, celana panjang hitam, dan membawa sapu lidi.Sebagian rambutnya ada yang tampak berdiri dengan ujung melengkung.Di belakang sosok laki-laki ini terlihat sebuah siluet hitam, dengan bentuk tubuh agak gempal dan sebagian rambut keatas, sedang membawa sapu juga.Kemudian disebelahnya lagi tampak sosok laki-laki mengenakan kaos putih yang berbadan gemuk, dengan benjolan di atas kepalanya dan bibir yang lebar terlihat membawa kemoceng (sulak).Di sebelahnya kanannya lagi ada sosok laki-laki berkaos putih, dengan rambut dikuncir ke belakang, dan bibir hitam lebar tampak tersenyum, sedang membawa ember.Dibelakangnya terlihat siluet sosok laki-laki dengan sebagian rambut yang panjang dikuncir ke belakang sedang membawa sekop. Lalu di sebelah kanannya lagi terlihat sosok laki-laki juga mengenakan kaos putih dan celana hitam, dengan hidung yang panjang serta mulut lebar tampak sedang memegang sebuah bohlam yang akan dipasangnya pada lampu kota disebelahnya. Disebelah kanannya lagi terlihat siluet yang tidak begitu jelas bentuknya dan apa yang sedang dikerjakannya karena terhalang gerobak sampah berwarna kuning yang ada di depannya. Pada posisi paling depan dari iklan ini tampak sosok laki-laki dengan menggunakan caping, bersepatu, dan mengenakan pakaian berwarna orange, sedang menyapu jalan raya menggunakan sapu lidi, dan tampak di depannya tumpukan sampah dan kepulan asap. Keseluruhan setting iklan terlihat berada di jalan raya, dengan trotoar yang dicat hitam putih berselang-seling.
Berdasarkan pada ciri dan motif artistik yang nampak dari visualisasi, iklan ini mempunyai kecenderungan gaya yaitu Art Nouveau. Hal ini dapat dilihat dari penggunaan motif lengkung-lengkung pada background headline dan ilustrasi mural bagian bawah.Art Nouveau, yang secara kata demi kata berarti seni yang baru. Muncul pada akhir abad ke-19 dan awal abad ke-20, yang amat berpengaruh dalam lingkungan yang cukup luas (hampir mencakup seluruh Eropa Barat), baik dalam seni lukis, seni ilustrasi, maupun dalam seni dekorasi, bahkan juga dalam seni arsitektur (Soedarso, 2000: 109). Corak ini dikenal dengan tanda-tanda yang cukup jelas, yaitu penggunaan (secara agak berlebihan) garis-garis yang melengkunglengkung yang ornamental, berdasar atas setiliran bunga-bungaan, daun-daunan, dengan sulur-sulurnya, dan kadangkadang lengkungan-lengkungan itu begitu panjang dan langsing seperti leher angsa. Gaya ini sekaligus memiliki sifat-sifat simbolik serta romantik yang konon merupakan pemberontakan terhadap materialisme industri di Eropa.

Singkatnya, menurut para pengkritik, Art Nouveau adalah gaya yang paling imajinatif dalam sejarah desain. Art Nouveau lahir di Inggris, yang merupakan negara pembawa perubahan di Eropa. Art Nouveau merupakan turunan dari gerakan gaya seni dan keahlian (Art and Crafts), terutama yang dilakukan oleh Arthur $\mathrm{H}$. Mackmurdo yang mengkombinasikan simbol-simbol dalam gaya Romantisme Pra-Raphael (Pre-Raphaelite Romantic) dengan keinginan untuk memperbaharui desain. Diawali pada sampul buku Arthur H. Mackmurdo, Wren's City Churches 
(1883), menggunakan motif dedaunan rindang yang merupakan ciri karakter Art Nouveau untuk pertama kali.Art Nouveau merupakan kombinasi yang aneh dari seni, kecerdasan, dan kepraktisan. Gaya estetis yang digunakan desainer Art Nouveau antara lain garis lengkung, pola abstrak bunga dan tumbuhan sebagai fungsi untuk menciptakan kesan ringan (Steven Heller\&Seymour Chwast, 1988:41).

Pada bagian paling bawah terdapat bidang biru bertuliskan Kedaulatan Rakyat "Korannya Rakyat" dan alamatnya yang berada di Jl. P. Mangkubumi 40-46 Yogyakarta 55232, Telp : 0274-565685, Fax : 0274-562229, Email : pemasaran@kr.co.id, www.kr.co.id.

Dalam iklan ini ada 2 jenis figur yang ditampilkan. Yang pertama yaitu figur seorang tukang sapu jalanan, yang diperlihatkan melalui figur laki-laki mengenakan caping, bersepatu, dan memakai pakaian berwarna orange, sedang menyapu jalan raya menggunakan sapu lidi, kemudian yang kedua adalah sosok beberapa laki-laki yang dilukiskan pada tembok (mural), yaitu :

1. Figur seorang laki-laki berkaos putih, bercelana panjang hitam, dan membawa sapu lidi. Sebagian rambutnya ada yang tampak berdiri dengan ujung melengkung, menggambarkan sosok Gareng.

2. Figur seorang laki-laki mengenakan kaos putih yang berbadan gemuk, dengan benjolan jambul rambut di atas kepalanya dan bibir hitam yang lebar terlihat membawa kemoceng (sulak), menggambarkan bahwa dia adalah Semar.

3. Figur seorang laki-laki berkaos putih, dengan rambut dikuncir ke belakang, dan bibir hitam lebar tampak tersenyum, sedang membawa ember, menggambarkan bahwa dia adalah Bagong,

4. Figur seorang laki-laki juga mengenakan kaos putih dan celana hitam, dengan hidung yang panjang serta mulut lebar tampak sedang memegang sebuah bohlam yang akan dipasangnya pada lampu kota, menggambarkan tokoh Petruk.

Keseluruhan figur laki-laki yang ada dalam mural tersebut digambarkan seolaholah sedang membantu si tukang sapu untuk membersihkan jalan di area itu.Konsep ilustrasi lebih mengedepankan kondisi dan situasi yang sebenarnya untuk mendukung tercapainya pesan yang ingin disampaikan.Tukang sapu sebagai representasi dari masyarakat bawah, sedangkan figur-figur yang membantunya tidak hanya berasal dari kalangan manusia, namun digambarkan dengan tokoh dalam dunia pewayangan, yaitu Punokawan.

Sebagian besar wayang dikerjakan menurut 'gaya wayang', yang secara dekoratif rumit, dan secara ikonografis ruwet, yang memberi penampilannya satu kesatuan tertentu, tetapi ada satu perkecualian penting yaitu, siluet-siluet serta penanganan figur-figur para pelawak. Bentuk-bentuk datar mereka secara fantastis aneh sekali dibuat garis besarnya dengan cara yang kuat dan sederhana; tak ada kerja terbuka yang secara dekoratif indah sekali pada busana yang sangat sedikit, tak satu hiasan pun pada kepala telanjang yang berumbai-rumbai. Semar tua yang bukan pria dan bukan wanita 
yang bertungkai pendek dan gemuk adalah berhidung penyek, dengan rahang yang menggembung sekali, satu mata yang lelah dan bijak, bagian belakang yang besar sekali, perut gendut yang menggembung, dan dada yang hampir seperti wanita. Anak-anaknya adalah Petruk yang berhidung panjang dan berbadan tinggi, Gareng yang pincang dan ketakutan.Anaknya yang ketiga yaitu Bagong, yang biasa tampil tetapi jarang, sekarang dilaporkan menjadi sangat popular (Holt, 1967: 200).Mereka adalah suara rakyat desa yang sederhana, dengan semua kekuatan mereka, kesengsaraan, dan kebijaksanaan mereka.

Semar dan Punokawan memberi dimensi baru dan mendalam pada etika wayang, sebagaimana di catat oleh Clifford Geertz(1969:275), eksistensi Semar dan anak-anaknya mengandung suatu relativisasi cita-cita priyayi mengenai satria yang berbudaya, halus lahir batinnya, sebagaimana terjelma oleh Arjuna. Bagi si priyayi, bentuk lahiriah yang halus merupakan jaminan batin yang halus pula, sedangkan lahir yang kasar tidak jarang dianggap sebagai pertanda batin yang kasar. Anggapan ini runtuh karena bertabrakan dengan kenyataan Semar.

Walaupun Semar kelihatan sebagai rakyat biasa saja, semua penonton tahu bahwa sebenarnya ia adalah seorang dewa yang tak terkalahkan. Semar mengatasi semua dewa lain dengan kekuatannya. Dewa-dewa disapanya dengan bahasa ngoko.Apabila Semar marah, dewa-dewa bergetar, dan apa yang dikehendakinya akan terjadi.

Dalam lakon-lakon dari siklus Mahabharata para Pandawa selalu
menang.Dilihat sepintas, kemenangan Pandawa itu karena kehebatan mereka.Tetapi sebenarnya tidaklah demikian, dan penonton Jawa menyadari hal itu juga. Kehebatan para Pandawa memang tidak dapat disangkal, tetapi tidak pasti akan menyelamatkan mereka. Bahwa Arjuna, apabila ia mengembara di hutan, aman dan terlindung itulah bukan karena kehebatannya sendiri, melainkan karena ia mempunyai sekelompok pengantar yang tidak akan meninggalkannya: Semar dengan anak-anaknya, yaitu para Punokawan. Siapa yang diantar Semar tidak pernah gagal dalam tugasnya dan tidak pernah kalah dalam perang.Selama para Pandawa diantar Semar mereka aman (Franz Magnis-Suseno, 1995:60).

Semar adalah ayah dari ketiga punokawan lainnya. Terbungkukbungkuk, dengan perut gendut, ia berjalan dengan lenggang yang khas. Dari ketiga anaknya, Gareng (atau Nalagareng) adalah yang sulung dan Bagong yang bungsu, Petruk-lah yang paling banyak akalnya.Gareng pengkor kakinya; Petruk tinggi kurus dengan hidung yang panjang sekali dan mulut yang membelah wajah dari telinga yang satu ke telinga lainnya.Mulut Bagong amat besar dan menutupi separuh wajahnya.Keempatempatnya memakai kain bermotif poleng, yang dianggap tanda kekuatan batin yang nyata (Denys Lombard bag.3, 2008:134).

Sudah sejak lama para tokoh Punokawan ini (baik secara sendiri-sendiri maupun bersamaan) tampil sebagai merek berbagai produk untuk masyarakat (makanan, minuman dan kebutuhan rumah tangga), penyampai pesan (poster-poster untuk ikaln layanan masyarakat, lukisan-lukisan 
kaca, komik), sarana promosi (iklan produk dan jasa) dan lain sebagainya.

Iklan ini merupakan seri ke-2 iklan PT Kedaulatan Rakyat untuk mengenang satu tahun pasca gempa bumi di Yogyakarta.Dalam iklan ini ditampilkan figur Panakawan (Semar, Bagong, Petruk, Gareng) yang sedang gotongroyong membantu seorang penyapu jalan.

Sosok Gareng yang sedang menyapu dan Bagong yang membawa tempat sampah merupakan simbol dari keberadaan orang lain maupun masyarakat daerah lain (bukan korban gempa bumi) yang turut membantu warga Yogyakarta dalam memulihkan kondisi paska gempa, bahu membahu membersihkan sisa puing yang diakibatkan oleh gempa bumi. Sedangkan visualisasi sosok Petruk yang terlihat membawa bola lampu dan hendak memasangnya pada lampu kota yang menjadi salah satu landmark Yogyakarta, merupakan simbolisasi dari adanya cahaya terang dan harapan bagi pemulihan Yogyakarta pasca gempa bumi jika konsepsi kebersamaan dan kegotongroyongan senantiasa dilakukan. Figur tukang sapu merupakan representasi dari kalangan masyarakat kelas bawah yang mayoritas menjadi korban gempa bumi.

Sosok Semar sebagai pemimpin Punokawan ditampilkan sedang membersihkan teks Bebarengan Mrantasi Gawe yang tertulis pada segumpal awan.Visualisasi tersebut merupakan simbol dari situasi pasca gempa Yogyakarta, dimana warga masyarakat saling tolong-menolong.Semar yang sedang membersihkan teks Bebarengan Mrantasi Gawe merupakan representasi dari bangkitnya kepedulian terhadap sesama yang sedikit luntur dan hilang karena imbas modernisasi dan kompleksitas masyarakat Yogyakarta.

Dalam budaya Jawa (khususnya Yogyakarta), wayang begitu dekat dengan masyarakatnya yang nyata.Dalam wayang tidak terdapat teori-teori umum, melainkan dengan model tentang hidup dan pola kelakuan manusia.Dilihat sepintas lalu, Semar dan anak-anaknya bukan tokoh utama dalam pewayangan.Fungsi Punokawan dalam cerita wayang terlihat hanya terbatas pada kelucuan dan melepaskan ketegangan yang memuncak disaat goro-goro. Figur Punokawan yang sedang bergotong-royong membantu menyapu jalan dalam iklan tersebut menginterpretasikan pengertian mendalam tentang apa yang sebenarnya bernilai pada manusia, bukan rupa dan fisik yang menjadi dasar penilaian, melainkan pembawaan yang sopan santun dan sikap batin yang peduli dan mau menolong terhadap sesama.

\section{KESIMPULAN}

Melalui simbolisasi figur Punokawan, iklan PT Kedaulatan Rakyat ingin membantah sekaligus menjatuhkan pandangan dan paradigma yang berlaku pada masyarakat bahwa makin tinggi kesaktian (tingkat martabat kehidupan manusia), jabatan, kekayaan dan hal lain yang bersifat kebendaan pada seseorang, semakin tinggi pula kedudukannya dalam masyarakat. Semar merupakan abdi dalem bagi Pandawa, tetapi kesaktiannya mengungguli semua dewa dan hanya 
karena perlindungannya para Pandawa bisa memenangkan perang Barathayuda.

Dengan digunakannya Punokawan dalam iklan tersebut, PT Kedaulatan Rakyat menampilkan kembali etos dan sifat gotong-royong (bebarengan mrantasi gawe)yang menjadi karakteristik masyarakat Yogyakarta. Selain itu iklan ini menggugah kembali sikap yang sering diucapkan sebagai sepi ing pamrih, rame ing gawe yang diartikan sebagai kesediaan manusia untuk dengan tenang dan rendah hati, tanpa pamor dan pamer memenuhi kewajibannya sehari-hari. Orang yang rame ing gawe tidak memaksakan dan mengusahakan kepentingannya sendiri, melainkan memberikan sumbangannya, betapapun sederhananya demi kesejahteraan dan demi keselarasan masyarakat dalam mengadapi bencana maupun proses rekonstruksi pasca bencana.

Pada dasarnya, iklan untuk mengenang satu tahun pasca gempa bumi di Yogyakarta tersebut memiliki tujuan sebagai sarana promosi dan identifikasi PT Kedaulatan Rakyat, namun dalam penyampaiannya lebih mengedepankan pesan moral dan spiritual.

\section{DAFTAR PUSTAKA}

1. Bing Bedjo, Punokawan Sebagai Media Komunikasi Visual, NIRMANA Vol. 6, No. 1, Januari 2004 : 36 - 51. Jurusan Desain Komunikasi Visual, Fakultas Seni dan Desain-Universitas Kristen Petra http://puslit.petra.ac.id/journals/design

2. Budiman, Kris. 1999. Kosa Semiotika. Yogyakarta: LKiS.

3. Cenadi, Christine Suharto. 1999. Elemenelemen dalam Desain Komunikasi Visual. Nirmana Vol.1.
4. Geertz, Clifford, 1969. The Religion of Java, The Free Press, New York.

5. Heller, Steven and Chwast, Seymour. 1988. Graphic Style From Victorian To Post-Modern, Time and Hudson Ltd, London.

6. Holt, Claire. 1967. Art in Indonesia: Continuities and Change. New York, Cornell University Press.

7. Judith Williamson, 2007, Decoding Advertisements : Membedah Ideologi dan Makna dalam Periklanan, Yogyakarta, Jalasutra.

8. Kasali, Rhenald. 1992. Manajemen Periklanan ; Konsep dan Aplikasinya di Indonesia". Jakarta , PT. Pustaka Utama Grafiti.

9. Lombard, Denys. 2008. Nusa Jawa : Silang Budaya, Warisan Kerajaan-kerajaan Konsentris. Gramedia Pustaka Utama, Jakarta.

10. Nuradi, dkk. 1996. Kamus Istilah Periklanan Indonesia. Jakarta, , Gramedia Pustaka Utama.

11. Sachari, Agus. 2005. Metodologi Penelitian Budaya Rupa. Jakarta, Erlangga.

12. Sobur, Alex. 2006. Analisis Teks Media, "Suatu Pengantar untuk Analisis Wacana, Analisis Semiotik, dan Analisis Framing". Bandung : PT. Remaja Rosdakarya.

13. Soedarso SP. 2000. Sejarah Perkembangan Seni Rupa Modern. Yogyakarta : BP.ISI \& CV.80 Enterprises.

14. Suseno, Franz Magnis, 1995. Wayang dan Panggilan Manusia, PT Gramedia Pustaka Utama, Jakarta. 